\title{
Modeling the Hydrodynamics and Salinity of El-Burullus Lake (Nile Delta, Northern Egypt)
}

\author{
A. El-Adawy, A. M. Negm, M. A. Elzeir, O. C. Saavedra, I. A. El-Shinnawy, and K. Nadaoka
}

\begin{abstract}
This study investigates issues related to hydrodynamics in Lake El-Burullus and flow patterns therein. Burullus Lake is the second largest lake in the northern Egyptian coast with a total area of $410 \mathrm{~km}^{2}$. It was utilized Delft3D-flow module to develop a field validated hydrodynamic model. The shallow brackish Lake is mainly affected by uncontrolled creeping of development areas and growing inflow of untreated agricultural, municipal and industrial drainage water. The developed model was used to examine a potential mitigation alternative by decreasing the pollutant loads that enter the Lake i.e. diversion of existing drains. In this fashion the creation of a new development area near-by may be feasible. In addition, the effects of hydrodynamics on pollutant dispersion either from an individual drain or all drains together. The results of this study will be the base for the water quality modeling stage. Actually, this work is the first stage of an integrated Lake management. The study concluded that the developed model efficiently simulated the hydrodynamics of the Lake which can act as an effective decision support tool for improving the environmental conditions in the surroundings.
\end{abstract}

Index Terms-Numerical simulation, hydrodynamic modeling, delft3d-Flow, shallow lake, circulation patterns, Nile delta.

\section{INTRODUCTION}

One of the most vulnerable areas along the delta's coastline is Burullus Lake. This is the second largest of the Egyptian northern lakes along the Mediterranean coast. It is located in the central part of the northern shoreline of the Nile Delta between longitudes $30^{\circ} 30^{\prime}-31^{0} 10^{\prime} \mathrm{E}$ and latitudes $31^{0} 35^{\prime}-31^{0} 21^{\prime} \mathrm{N}$. The lake is shallow, with a maximum depth of $175 \mathrm{~cm}$ in the middle and western parts. The lake surface area is $410 \mathrm{~km}^{2}$. The brackish lake salinity levels range from $2.1 \%$ in the west to $17.2 \%$ in the north [1]. The flushing rate is 61 days, i.e. lake water is renewed 6 times a year [2].

The most important challenges facing El-Burullus Lake are:

- Fish productivity: During 2000 - 2002 periods, a field

Manuscript received August 17, 2012; revised November 18, 2012.

A. El-Adawy, A. M. Negm, M. A. Elzeir, O. C. Saavedra, and K. Nadaoka are with Energy Resources and Environmental Engineering Department, Egypt- Japan University of Science and Technology E-JUST, New Borg Elarab, Alexandria, Egypt (e-mail: ahmed.eladawy @ejust.edu.eg, Abdelazim.negm@ejust.edu.eg)

O. C. Saavedra is with the Department of civil Engineering, Graduate School of Science and Engineering, Tokyo Institute of Technology, Tokyo, Japan (e-mail: saavedra.o.aa@m.titech.ac.jp)

I. A. El-Shinnawy is with Coastal Research Institute, Alexandria, Egypt (e-mail: coriegypt@yahoo.com)

K. Nadaok is with the Department of Mechanical and Environmental Informatics, Graduate School of Information Science and Engineering, Tokyo Institute of Technology, Tokyo, Japan (email: nadaoka@mei.titech.ac.jp) survey [3] showed that the diversity of fishes in Lake Burullus was declined from 32 species to 25 ones. Another group of researchers could sample 21 species were sampled at El-Boughaz in 1971 [4].

Total fresh water fish increased from $81.7 \%$ to $98.18 \%$ by weight during the period between 1971 and 2003 while the total marine fish decreased from $15.99 \%$ to $1.81 \%$ by weightas the salinity levels are decreasing according to the massive increase of the agricultural drainage water inflow [5].

Water quality challenge: The Lake serves as reservoirs for drainage waters, from agricultural areas through nine drains in addition to the fresh water from Brimbal Canal situated in the western part of the lakeas shown in Fig. 1. The lake receives drainage water at a rate that fluctuated between $78 \times 10^{6}$ and $272 \times 10^{6} \mathrm{~m}^{3} /$ month during January and July 2002 , respectively. The amount of drainage water that is discharged annually into the lake is varying from one year to the other, with an average amount of about 2.5 billion $\mathrm{m}^{3} /$ year [6].

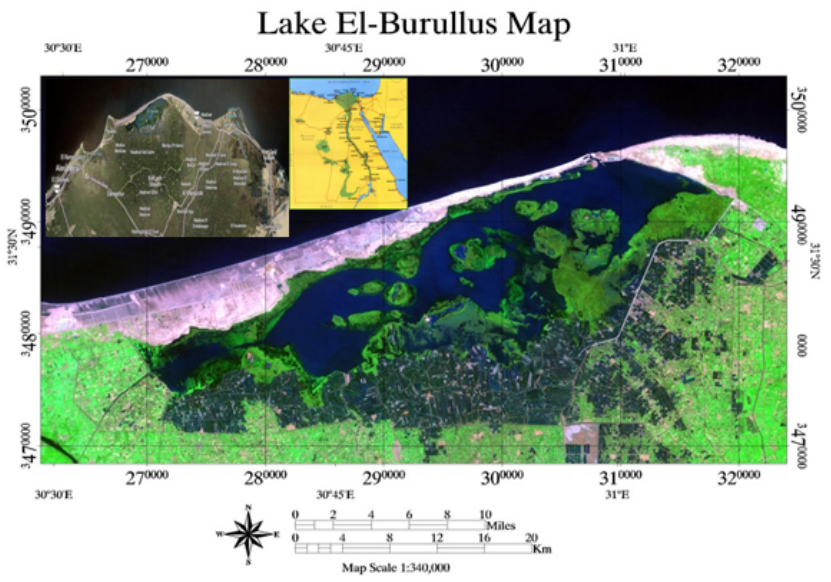

Fig. 1. Geography of lake el-Burullus

Several physical factors combine to make the coastal systems complex and unique in their hydrodynamics and the associated physical transport and dispersal processes of the coastal flow field are equally complex [7].Modeling the circulation inside the lake is an essential tool in order to investigate the Lake water balance and its flushing rate.

Through the literature, some studies recently discussed the hydrodynamics of the coastal lakes in Egypt. Bek et al applied the ocean model (FVCOM) to replicate the hydrodynamic flows experienced within Lake El-Manzala, Egypt [8]. However, Amel developed a detailed 2D hydrodynamic model of the shallow lake, and a 2D water quality and eutrophication screening models for the Lake Edku system [9]. Linnersund and Mårtensson estimatedthe exchange rates for Bardawil Lagoon, Egypt [10]. Rasmussen et al. investigated the influence that a reduced inflow nutrient 
load may have on Lake El-Manzal water quality through hydrodynamic- ecological modeling [11].

The current study is considered the first study which deals with the water hydrodynamics of El-Burullus Lake. The developed field validated 3D and depth averaged model will enhance our understanding of the hydrodynamic behavior of Lake El Burullus. The next step is to construct a full waterquality model through a coupling process with the hydrodynamic model. In this study, the applied forces in the model are wind speed and direction, atmospheric pressure, air temperature, humidity and solar radiation for calculation of heat exchange with the atmosphere, water levels, temperature and salinity at the model marine boundary and freshwater inflow from the drains. These are the expected outcomes of the study:

1) To represent the seasonal variability in hydrodynamic conditions inside the lake. The hydrodynamic conditions include both general circulations inside the lake and degree of stratification inside the lake and at the inlet zone.

2) To validate and calibrate the hydrodynamics model (water-level, salinity and temperature) over the range of conditions typically experienced in one year.

3) Check the feasibility of diversion some drains from discharging into the Lake to discharge into Mediterranean Sea directly from the hydrodynamic point of view.

4) To simulate the pollutant dispersion process within the lake domain.

\section{MATERIALS AND MethodS}

\section{A. Hydrodynamic and Meteorological Datasets}

The Drains' discharges, water levels, tidal variation as components of the hydrodynamic data sets and wind vectors, solar radiation, relative humidity, and temperatures as components of meteorological datasets are used for the calibration and validation process of the developed model. In addition, geometric data include bathymetry, land boundaries, island boundaries and positions of drains were used in determining the closed, open boundaries of the model and creating the grids.

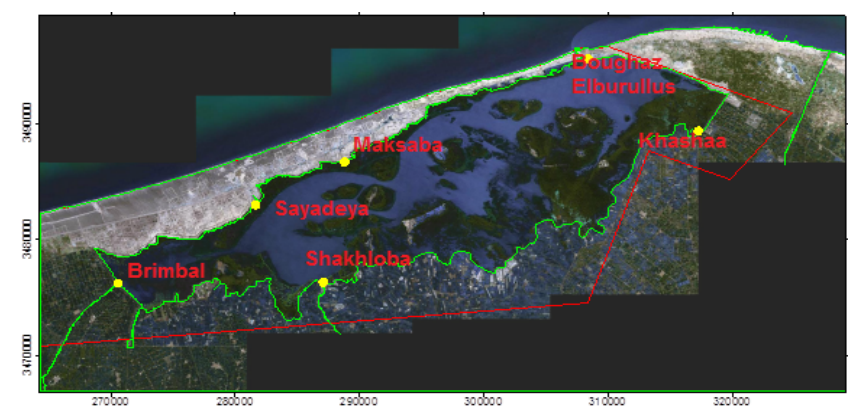

Fig. 2. Stations monitoring water levels in Lake Burullus

Water levels for the period ranged from 6/8/2004 to 31/7/2005 were collected by Coastal Research Institute CoRI using stage boarder in stations shown in Fig. 2. Data were collected two times a day. These water level data are presented in Fig. 3. Wx-Tide, a free Windows tide and current prediction was employed for tidal predictions in this Paper. In this study, WxTide was utilized to generate records for two years 2004 and 2005. The discharges rates of the drains are shown in Fig. 4. These data were obtained from pumping station records presented in El-Shinnawy [12]. Salinity levels inside the lake in the same period of simulation and spatial distribution of temperature were measured by El-Sayes [13].

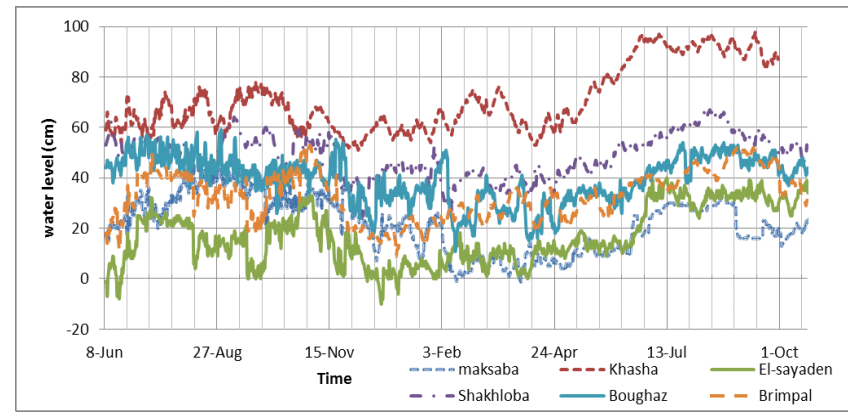

Fig. 3. Water levels in Lake Burullus

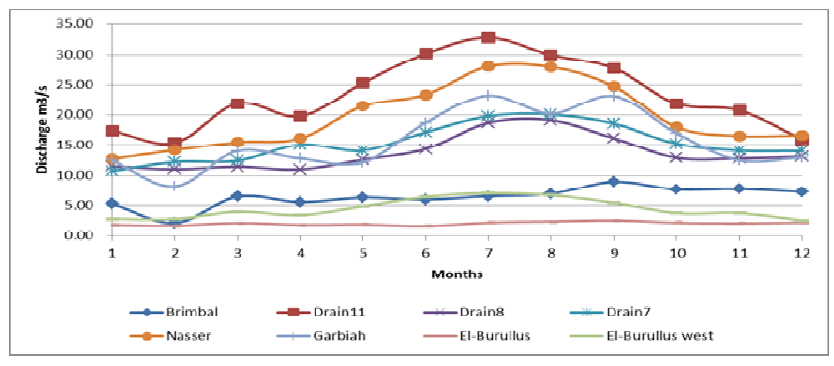

Fig. 4. Drains' discharges into Lake el-Burullus

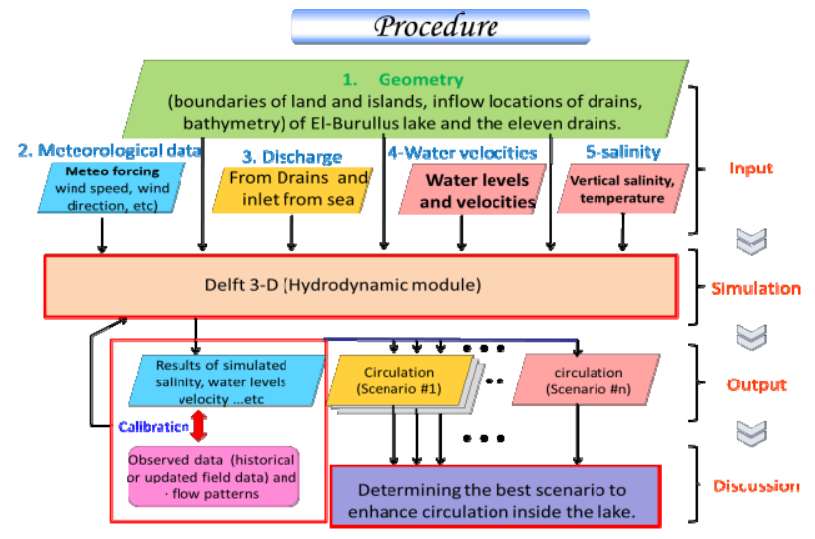

Fig. 5. Procedure of the study

The climate of Burullus protected area is arid Mediterranean. The mean annual rainfall is less than $200 \mathrm{~mm}$. The summer months (June - September) are almost entirely rainless, while the winter months (November - February) are the wettest [14]. The temperature typically varies from $9^{\circ} \mathrm{C}$ to $30^{\circ} \mathrm{C}$ and is rarely below $6^{\circ} \mathrm{C}$ or above $32^{\circ} \mathrm{C}$. El-Burullus weather station data were used while online data sets that were used to fill the gaps in field measurements. The online data sets are mainly from wunderground.com. The warm season lasts from June 6 to October 10 with an average daily high temperature above $28^{\circ} \mathrm{C}$. The hottest day of the year is August 5, with an average high of $30^{\circ} \mathrm{C}$ and low of $24^{\circ} \mathrm{C}$. The cold season lasts from December 10 to March 21 with an average daily high temperature below $20^{\circ} \mathrm{C}$. The coldest day of the year is February 2, with an average low of $9^{\circ} \mathrm{C}$ and high of $18^{\circ} \mathrm{C}$. 


\section{B. Hydrodynamic Model Setup}

A successful model application requires a model calibration that compares simulated results with measured lake conditions [9]. The procedure of this work is shown in Fig. 5.

A grid of finite difference quadrangular elements was created for the entire Lake with about 66000 cells as shown in Fig. 6 The resolution of the grids is between $20 \mathrm{~m}$ to $270 \mathrm{~m}$.

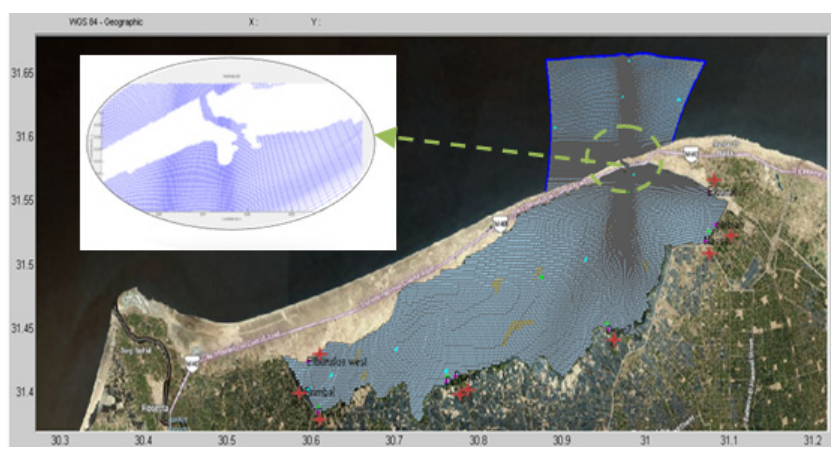

Fig. 6. Grid used in the model. elements in inlet channel (Boughaz) are refined. Grids are shown in delft dashboard window.

RGFGRID (preprocessing software) is used for creating orthogonal curvilinear grids. A curvilinear grid allows a high grid resolution near the area of interest and a low grid resolution outside this area so the total number of cells is reduced and so the computational time. Quickin (preprocessing software) was used to combine and create bathymetries and assigning data of sample points to the cells. In addition, It is used to check the orthogonally, smoothness and aspect ratio of the grids. DelftDashBoard is a Matlab-based user interface that couples model input with both online and offline databases. It was used to get data of bathymetry for unmeasured areas (in sea side of the lake) and tidal data and also was used to combine these data to be used in the mdf file that defines each run.Using flow-input tool, one can define the grid parameters, dry points, initial conditions, and numerical parameters....etc. The model boundary conditions are chosen to be the discharge inflow from 9 drains, and the tidal variation of water level at the sea inlet to the lake Observation stations results are compared with the real values measured there to calibrate the model to properly simulate the situation of the Lake. After trials, the initial water level in the lake is set to $0.5 \mathrm{~m}$ and salinity is set to 3 ppt.

\section{Relative Difference between $T s=1$ minute and $T s=0.5$ minute \%}

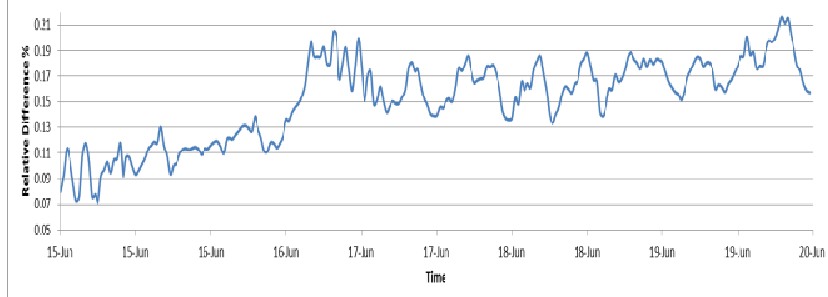

Fig. 7. Relative difference $\%$ in water level values in case of $T_{s}=1$ minute and $T_{s}=0.5$ minute.

The purpose of deciding an appropriate time step is to reduce the simulation duration (i.e., execution time). Underestimation of the time step results in unnecessarily long simulation run times, whereas overestimation leads to errors inthe model calculations [10].Generally, the Courant number should not exceed a value of ten.So an initial guess of 1 minute is used as a time step then the relative difference at an observation station (mid of the lake) is computed in both cases (using 1 minute and 0.5 minute as time steps) as shown in Fig. 7. To make sure that the time step value is not underestimated the spatial distribution of courant numbers for all the cells was computed and shows that courant number is between 0-3 all over the Lake.

A spacially varied bottom roughness was developed using manning roughness coeffients between 0.02 and 0.088 for floating leaved rooted plants as stated by environmental agency in 2008. The areas of floating vegetation were determined by a supervised classification using landsat imagery of the same period. The classified image is shown in Fig. 8.

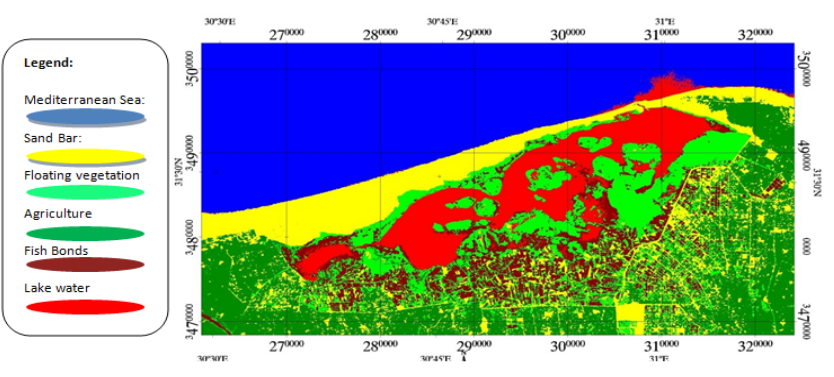

Fig. 8. Classified image of the year 2003

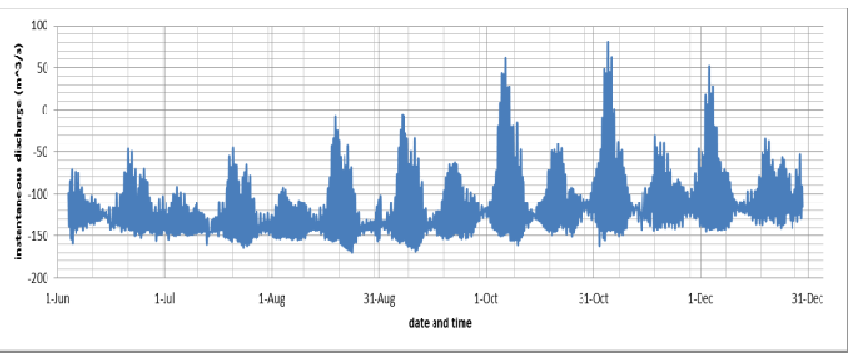

Fig. 9. Simulated instantaneous discharge between the Lake and the Sea.

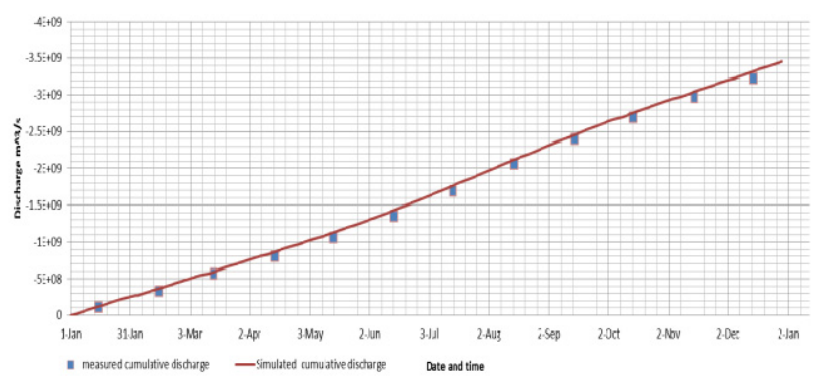

Fig. 10. Simulated and measured accumulative discharge between the Lake and the Sea.

El-Shinnawy [15] suggested a method for reusing drainage water and for establishment of marine eco-system. First the excess water could be discharged to the Mediterranean Sea through a proposed canal number (1) that connects Al-Moheet drain to Al-Gharbia main drain. So this engineering solution was investigated in the model to know how it would affect the circulation patterns, water levels and salinity inside the Lake.

The calibration process was performed in order to increase the accuracy of the model against measured data. The model was calibrated using water levels, discharges and salinity. 
Some scenarios were performed to test how the Lake hydrodynamics reacts with changing the forces. These scenarios include 2-D and 3-D modeling of the hydrodynamics inside the Lake.

\section{RESUlTS AND DISCUSSION}

Delft-3D flow was utilized to develop the hydrodynamic model for Lake El-Burullus. The model was calibrated using the data available of monthly averaged discharges, daily averaged water levels and monthly averaged salinity and temperature. Simulated exchange between Lake and Sea at cross section in El-Boughaz is shown in Fig. 9. It should be noticed that negative value indicates that the discharge is from lake to sea and vise-versa. Simulated accumulative discharge at the same section is compared to the measured accumulative discharge by Elshenawy [15] as shown in Fig. 10 , the results are well matched.

The simulated water levels in shakhloba station are compared to the available water levels. Fig. 11 shows the comparisons between simulated and measured water levels at Shakhloba station. The variations in some positions on the curves are caused by lack of continuous recording of water levels and the error and uncertainty in the manually measured data. In addition the wind data used in the simulation is from one station beside the Lake not well distributed stations all over the Lake. Furthermore, the discharges used in this work is monthly averaged which isn't completely equivalent to what happens in actual case. Fig. 12 shows the simulated water level in three stations inside the Lake which are Boughaz, west station and mid station.

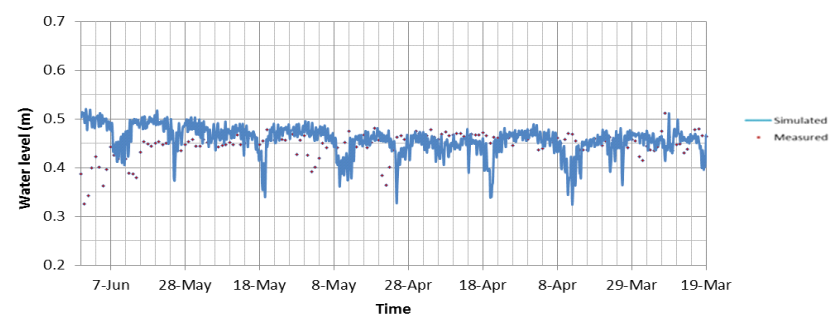

Fig. 11. Simulated water levels at Shakhloba station compared to the measured value

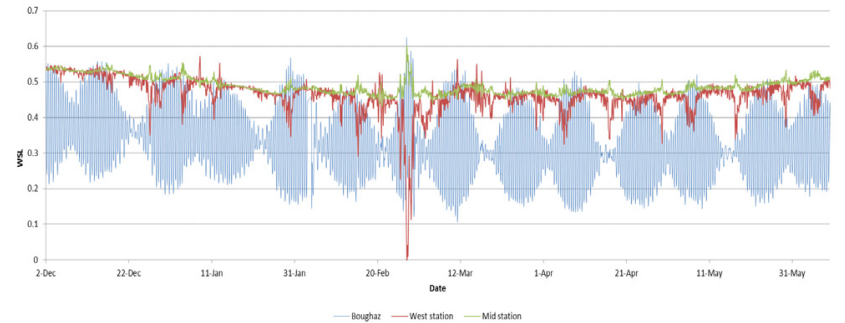

Fig. 12 simulated water levels at Boughaz, Mid and West station

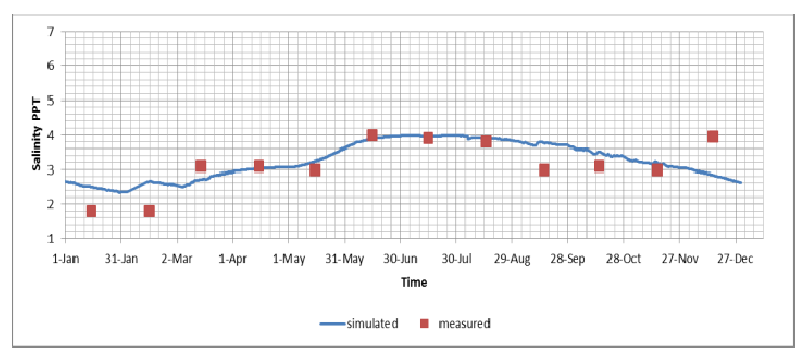

Fig. 13-a

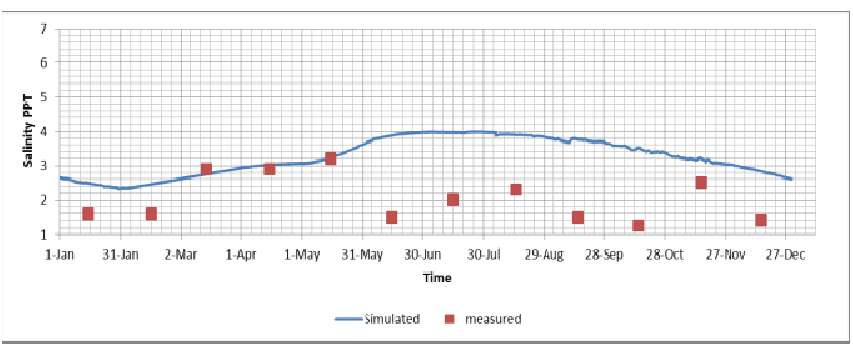

Fig. 13-b

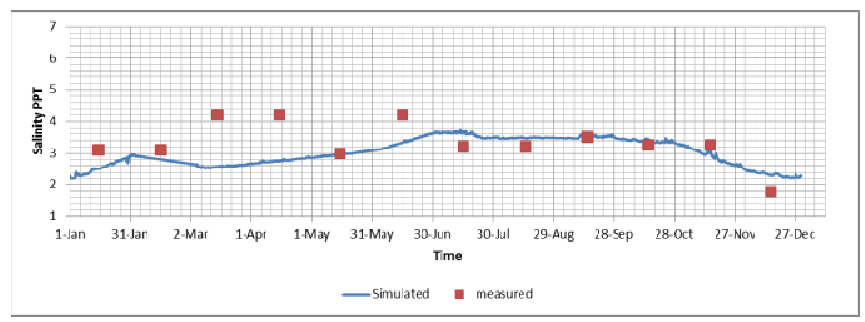

Fig. 13-c

Fig. 13. Simulated and measured salinities at three stations (west, middleand east respectively).

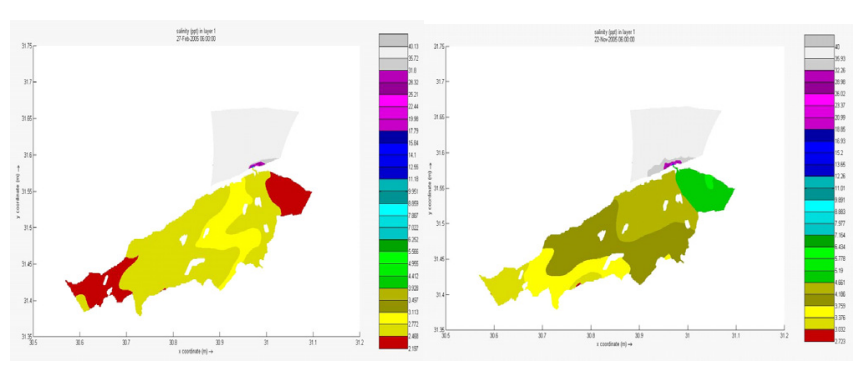

Fig. 14. Spatial distribution of simulated salinity in February (left) and November (Right) respectively.

The measured and simulated salinities at 3 stations covering the three main portions of the lake which are the east, middle and west portion are shown in Fig. 13. The west and east shows very good agreement with the measured salinity. There are variations in the middle station between measured and simulated salinity. Unlike the east and west portions, the middle portion contains islands and is considered to be the only area where the water from all drains flow through. These factors affect the accuracy of the results in the middle portion of the Lake. The seasonal spatial distribution of salinity in the Lake is shown in Fig. 14. It should be noticed that only the area around the inlet channel (Boughaz area) because generally the flow direction is from Lake to the Sea as discussed before in Fig.10.

The velocity magnitude and direction pattern of outflow around the inlet are shown in Fig. 15. Currents and eddies in all portions of the Lake are shown in Fig. 16. Near the open boundary, the velocity vector is affected mainly by the tidal forces. Inside Boughaz or the channel links the sea and the Lake can reach $1 \mathrm{~m} / \mathrm{s}$. Inside the Lake where the velocity vector is mainly affected by wind direction the velocity is between 0 and $0.08 \mathrm{~m} / \mathrm{s}$. Clockwise and anti-clockwise eddies are generated at different positions inside the Lake and they are independent of tides. It also should be noticed that the effect of drains' discharges on velocity vectors is limited to the areas near their inlets. The comparisons in Fig. $17 \mathrm{~A}$ and Fig. $17 \mathrm{~B}$ show the effect of wind on the values of depth averaged velocity. 


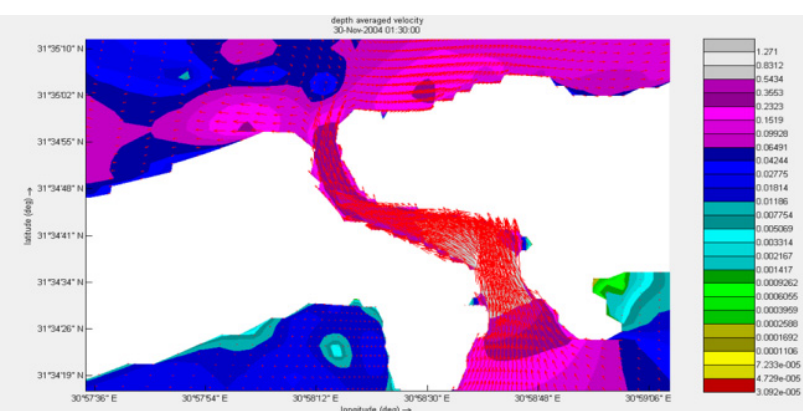

Fig. 15. Velocity magnitude and direction at one shot of inflow around the inlet

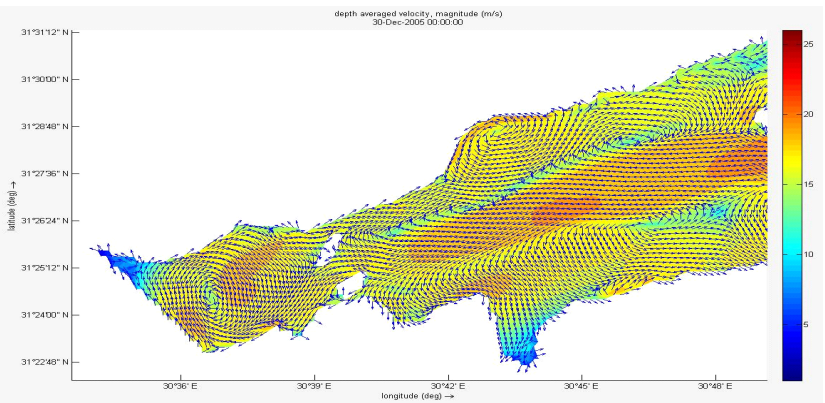

Fig. 16. Velocity vectors and magnitude on one shot inside the lake show the formation of Currents and Eddies

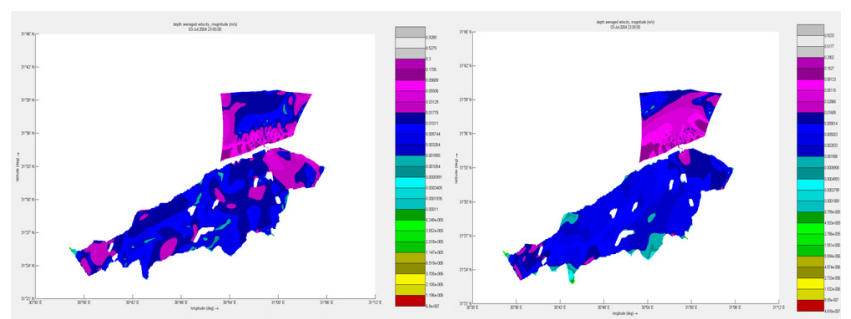

Fig. 17. A On the left: one shot of the depth averaged velocity with the existence of wind forces. on the right: one shot of the depth averaged velocity with the absence of wind forces at the same time step.

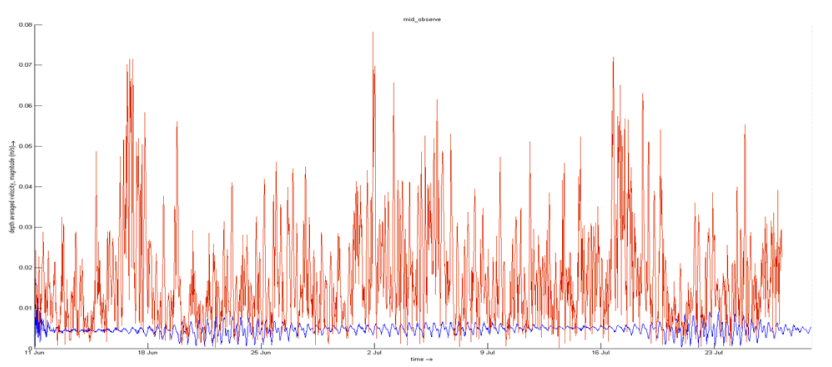

Fig. 17. B Simulated depth averaged velocity magnitude at mid station under the effect of wind (Red) and without wind effect (Blue).

The spatial distribution of water temperature after applying the heat flux model using relative humidity, air temperature, solar radiation and sky cloudiness as inputs for the model was computed. In Absolute flux model, the absolute temperature is computed. The relative humidity, air total solar radiation temperature and the (short wave) solar radiationfor a clear sky have to be prescribed. The net atmospheric (long wave) radiation and the heat losses due to evaporationand convectionare computed by the model.

Fig. 18 shows an aggrement between simulated and measured depth averaged temperature at the mid station. Drogues simulate efficiently the circulation inside the lake. Fig. 19 shows all the simulated paths on these drogues that released with the start time of simulation in 1/12/2004 till $1 / 2 / 2005$ for about two months. It should be noticed that the drogues took about 2 months from drains no.7, no.8 and Gharbeya to reach open boundary but for the west part the simulated drogues still trapped in this portion for more than 2 months which implies that this portion has the longest renewal time.

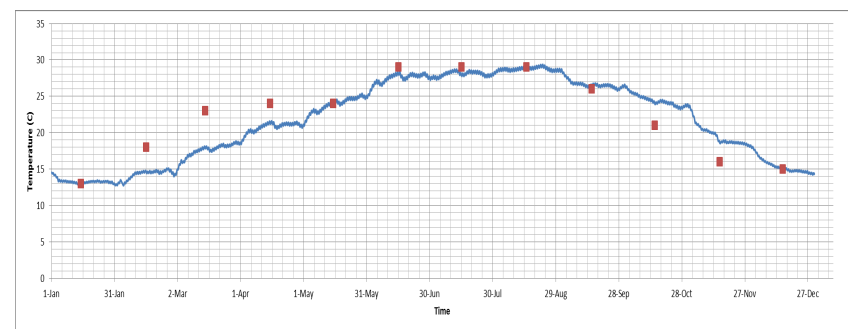

Fig. 18. Simulated and measured temperature at a mid-station in the lake.

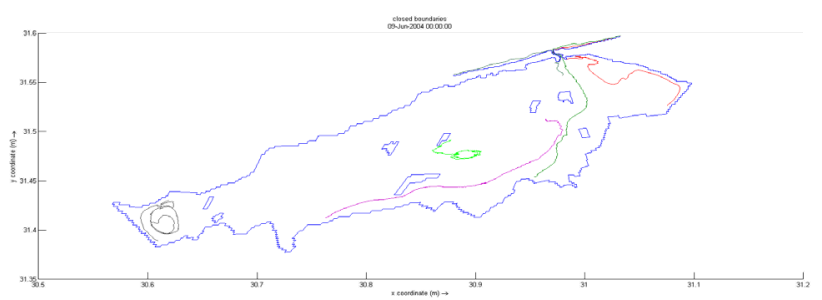

Fig. 19. Paths of drogues released from different points in the Lake.

From the results of the 3-D modeling one can conclude that Lake El-Burullus is a shallow well mixed water body. This is due to the lake shallowness and the wind effect. In shallow water wind leads to strong vertical mixing as stated by Falconer et al [16]. Except for the link between the Lake and Sea, the lake water is well mixed and little difference between the bottom and surface water temperature. Fig 20 shows the vertical velocity, temperature and salinity distribution in a cross section in the inlet channel shows the intrusion of saline into the brackish water.

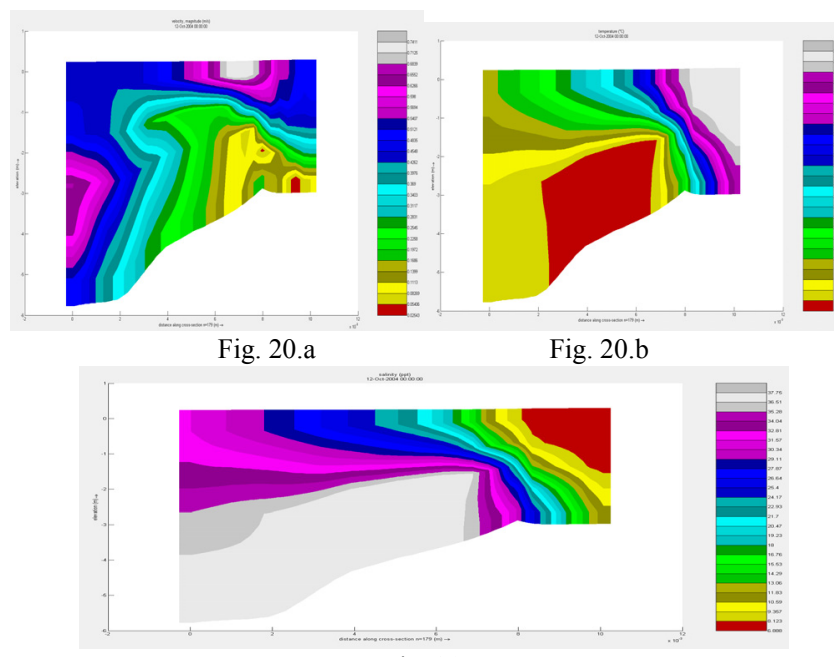

Fig. 20-c

Fig. 20. The vertical velocity, temperature and salinity distribution in a cross section in the inlet channel

The developed model was utilized to examine the effect of the proposed solution of diversion of drains discussed before on the Lake Hydrodynamics and spatial distribution of salinity. Fig. 21 shows the predicted water levels in case of the absence of the west drains (no.11, no.9, no.8 and Burullus west). In Fig. 21 one can notice that the Lake becomes shallower. Fig. 22 shows salinity distribution in the absence of west drains mentioned before. From the figure one can 
notice how salinity increases when reducing the discharges from drains, however it is only effective in areas near Boughaz and areas far from Boughaz still have low salinity. Fig. 23 shows the effect of the absence of all drains on the salinity distribution. One can notice that the salinity will be significantly changed when all the drains stop discharging in the Lake.

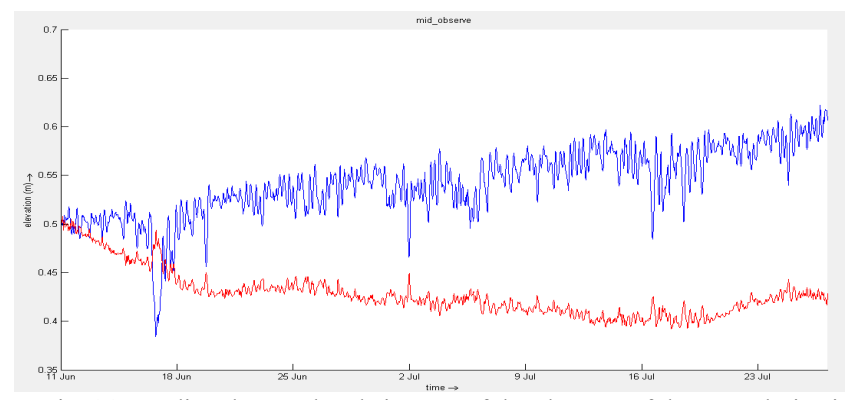

Fig. 21. Predicted water levels in case of the absence of the west drains in mid station inside the Lake.

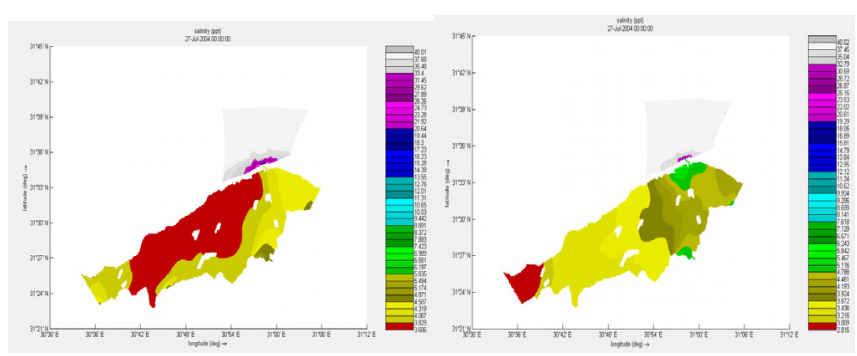

Fig. 22. On the left: one shot of the salinity distribution with the existence of all drains. on the right: one shot of the salinity distribution with the existence of only 5 drains at the same time.

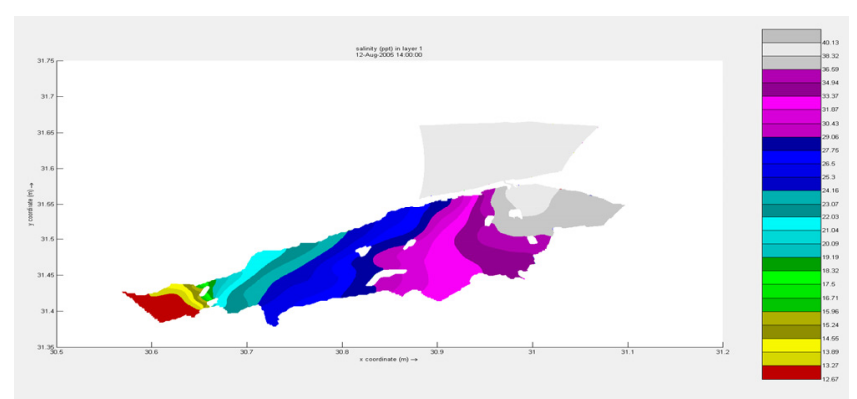

Fig. 23. The spatial distribution of simulated salinity in the Lake in case of the absence of all drains.

To simulate the effects of pollutant dispersion within the lake domain, it was decided to employ a surrogate tracer dye that may be released through the various inflows [17]. Firstly, dye concentrations of $1 \mathrm{Kg} / \mathrm{m}^{3}$ were released on one drain Nasserto simulates transport of pollutants from the drain. Then in another simulation the dye concentrations were released from all drains on the same time to simulate the combined effects of pollutant dispersion. Fig. 24 to Fig. 25 shows the dye patterns development during a month from their release. In case of Brimbal case, it took more time to spread than what happened in case of Nasser. Although drain Nasser is near the Boughaz, the dye takes 5 months to spread all over the lake so we can conclude that pollutants from drains of the east and the west portions of the Lake affect all water body of the Lake.

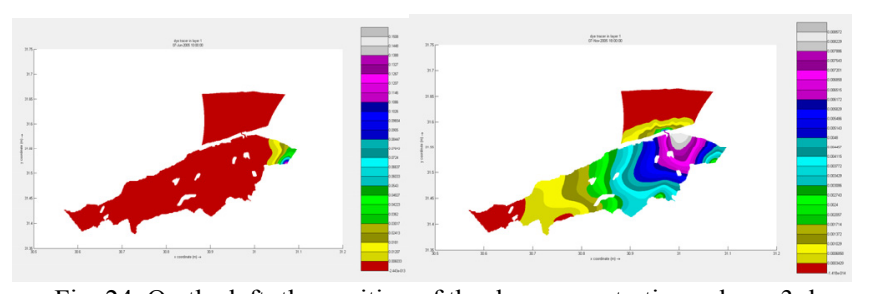

Fig. 24. On the left: the position of the dye concentrations plume 3 days after it was released from drain Nasser. on the right: The position of the dye concentrations plume five months after it was released from drain Nasser.

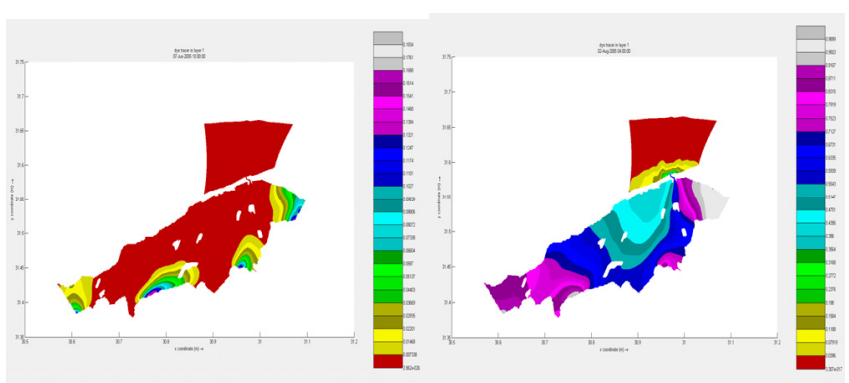

Fig. 25. On the left: the position of the dye concentrations plume two days after it was released from all drains. on the right: The position of the dye concentrations plume two months after it was released from all drains.

\section{CONCLUSION}

To the best of the authors' knowledge, this is the first study utilizes the data available of El-Burullus lake to build a validated hydrodynamic model that can be efficiently simulate the hydrodynamic situation in El-Burullus Lake. This can help to asses any proposed engineering solution for preserving the aquatic system of the Lake and stop the continuous deteriorating of the water quality. The simulation results revealed that the main driving forces that are responsible for the circulation patterns inside the Lake is wind and drains' discharges. The main factors that are responsible for the spatial distribution of salinity inside the Lake is drains' discharges especially for areas far from Boughaz as most of the time as simulated the dominant direction of flow is from the Lake to the sea except few days of high northerly blown wind that leads to high salinity measurements near inlet. In addition, absence of some drains (less than 4 drains) directly leads to lowering the water level and transforming their receiver areas to stagnant areas and has no significant effect on salinity distribution except near Boughaz area. Significant increase of salinity distribution is noticed when all drains stop discharging the Lake as discussed in the study.

Furthermore, the water body is considered to be well-mixed while obvious stratification could be found in the inlet channel. Retention time isn't the same all over the Lake and the maximum retention time is found in the western part where the minimum retention time is found near Boughaz. A pollutant coming from any drain affects the whole area of the Lake even if this drain is in the east part of the Lake near Boughaz. A permanent monitoring system should be established to get continuous records of both hydrodynamic and water quality parameters and should cover all parts of the Lake.

\section{ACKNOWLEDGMENT}

The first author is supported by a scholarship from the 
Mission Department, Ministry of Higher Education of the Government of Egypt which is gratefully acknowledged. He is also grateful for his earlier supervisor Dr. Mohammed El-Zier who passed away on August 17, 2012.

\section{REFERENCES}

[1] A. Zalat and S. S. Vildary, "Distribution of diatom assemblages and their relationship to environmental variables in the surface sediments of three northern Egyptian lakes," Journal of Paleolimnology, vol. 34, no. 2, pp. 159-174, 2005.

[2] A. Darrag, "The occurrence and distribution of some trace metals and their relation to organic matter," Ph.D. dissertation, Faculty of Science, Alexandria University, Alexandria, Egypt, 1985.

[3] M. T. Khalil and F. A. E. Dawy, " Ecological Survey of Burullus Natural Protectorate: Fishes and Fisheries," Med Wet Coast Project, Egyptian Environmental Affairs Agency (EEAA), Cairo, 2002.

[4] J. Libovarsky, S. Lusk, and H. M. E. Sedfy, "Fishery survey carried out at Lake Borullus," vol. 6, no .7, pp. 1-42, 1972.

[5] A. A. Sayes, A. Radwan, and L. S. Hakweer, "Impact of drainage water inflow on the environmental conditions and fishery resources," Egyptian Journal of Aquatic Research, vol. 33, no.1, pp 312-321, 2007.

[6] A. A. Samaan, A. F. Ghobashy, and M. AboulEzz, "The benthic fauna of lake Burullus: 1. Community composition and distribution of the total fauna," Bull. Nat. Inst. Oceanogr. And Fish, Egypt, vol. 15, no. 1, pp. 217-224, 1989.

[7] Y. R. Rao and D. J. Schwab, "Transport and mixing between the coastal and offshore waters in the Great Lakes: a review," J. Great Lakes Res, vol.33, pp. 202-218, 2007.

[8] M. A. Bek and I. S. Lowndes. (2010). the application of a validated hydrodynamic model to improve the water management of an Egyptian shallow water coastal lake. [Online]. Available: http://goo.gl/xkl2e .

[9] A. M. Azab. (2012). Integrated gis, remote sensing and mathematical modeling for surface water quality management in irrigated water sheds. [Online]. Available: http://goo.gl/BaUb3 .

[10] J. Linnersund and E. Mårtensson. "Hydrodynamic modeling and estimation of exchange rates for Bardawil Lagoon. [Online]. Available: http://goo.gl/qbWvu .

[11] E. Kock Rasmussen, O. Svenstrup Petersen, J. R. Thompson, R. J. Flower, and M. H. Ahmed. (2009). Hydrodynamic-ecological model analyses of the water quality of Lake Manzala (Nile Delta, Northern Egypt). 622(1). pp. 195-220. [Online]. Available: http://goo.gl/6DZUy.

[12] I. A. E. Shinnawy, "Hydrological Study for Al-Burullus wetland," Egyptian Environmental Affairs Authority, EEAA, National Preservation Department, Wetland Sector, Cairo, Egypt, 2002.

[13] A. Alsayes, A. Radwan, and Shakweer, "Impact of drainage water inflow on the environmental conditions and fishery resources of Lake
Burullus," Egyptian journal of aquatic research," vol.3 3, no. 1, pp. 312-351, 2007.

[14] M. Kassas et al., "Management plan for Burullus Protected Area. Med Wet Coast," Global Environment Facility and Egyptian Environment Affair Agency, 2002.

[15] I. A. E. Shinnawy, "Water Budget Estimate for Environmental Management at Al-Burullus Lake, Egypt," in Proc. of 4th International Conference and Exhibition for Environmental Technologies Environment, 2003.

[16] R. A. Falcon, D. G. George, and P. Hall, "Three-dimensional Numerical modeling wind driven circulation in a shallow homogenous lake," Journal of Hydrology, vol. 124, no. 2, pp. 59-79, April 1991.

[17] M. A. Bek, "The Numerical Simulation of Shallow Water Coastal Lake, Lake El-Manzala, Egypt," Ph.D. dissertation, Department of Chemical and Environmental Engineering, University of Nottingham, 2011.

Ahmed El-Adawy was born in Mansoura, Egypt, on June, 1988. He obtained B.Sc. in Civil Engineering from Mansoura University, Egypt, in 2010. The Cumulative average grade is; Distinction with Honor's Degree. Since 2011 until now is M.Sc. student with Department of Energy Resources and Environmental Engineering Department, Egypt-Japan University of Science and Technology E-JUST, Alexandria, Egypt.

2010- 2011 Demonstrator, Irrigation and Hydraulics Dept., Mansoura University, Egypt. He is interested in the hydrodynamic modeling and applications of remote sensing in coastal areas.

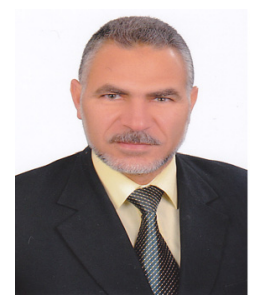

Abdelazim Negm was born in Sharkia, Egypt. His background is Civil Engineering because he was graduated from Irrigation and Environmental Engineering Dept. in 1985.Prof. Negm has got his M.Sc. from Ain Shams University in 1990 in Hydrology of the Nile Basin. He got PhD degree in 1990 in Hydraulics.

Currently, he is a professor of water resources in Egypt-Japan University for Science and Technology since Oct. 2012.He worked as demonstrator in Faculty of Engineering, Zagazig University in 1986 and continued till he occupied the position of Vice Dean for Academic and Student Affair. He was promoted as professor of hydraulics. His research areas are wide to include hydraulic, hydrology and water resources. He published more than 170 scientific papers in national and international Journals and conferences. He is listed in (a) Marquis Who is Who?, (b) IBC's 2000 Outstanding Intellectuals of the 21 st Century , and (c) ABI directory for his achievement in the field of Hydraulics and Water Resources. He participated in more than 50 conferences. He has awarded the prizes of best papers three times. He participates in the two EU funded international projects. For his detailed information one can visit his website www.amneg.name.eg and www.amnegm.com . 